\title{
Congenital heart diseases: genetics, non- inherited risk factors, and signaling pathways
}

\author{
Emmanuel Suluba ${ }^{1,2^{*}}$ (D), Liu Shuwei ${ }^{1,2}$, Qing Xia ${ }^{1,2}$ and Ally Mwanga ${ }^{3}$
}

\begin{abstract}
Background: Congenital heart diseases (CHDs) are the most common congenital anomalies with an estimated prevalence of 8 in 1000 live births. CHDs occur as a result of abnormal embryogenesis of the heart. Congenital heart diseases are associated with significant mortality and morbidity. The damage of the heart is irreversible due to a lack of regeneration potential, and usually, the patients may require surgical intervention. Studying the developmental biology of the heart is essential not only in understanding the mechanisms and pathogenesis of congenital heart diseases but also in providing us with insight towards developing new preventive and treatment methods.

Main body: The etiology of congenital heart diseases is still elusive. Both genetic and environmental factors have been implicated to play a role in the pathogenesis of the diseases. Recently, cardiac transcription factors, cardiacspecific genes, and signaling pathways, which are responsible for early cardiac morphogenesis have been extensively studied in both human and animal experiments but leave much to be desired. The discovery of novel genetic methods such as next generation sequencing and chromosomal microarrays have led to further study the genes, non-coding RNAs and subtle chromosomal changes, elucidating their implications to the etiology of congenital heart diseases. Studies have also implicated non-hereditary risk factors such as rubella infection, teratogens, maternal age, diabetes mellitus, and abnormal hemodynamics in causing CHDs.

These etiological factors raise questions on multifactorial etiology of CHDs. It is therefore important to endeavor in research based on finding the causes of CHDs. Finding causative factors will enable us to plan intervention strategies and mitigate the consequences associated with CHDs. This review, therefore, puts forward the genetic and non-genetic causes of congenital heart diseases. Besides, it discusses crucial signaling pathways which are involved in early cardiac morphogenesis. Consequently, we aim to consolidate our knowledge on multifactorial causes of CHDs so as to pave a way for further research regarding CHDs.

Conclusion: The multifactorial etiology of congenital heart diseases gives us a challenge to explicitly establishing specific causative factors and therefore plan intervention strategies. More well-designed studies and the use of novel genetic technologies could be the way through the discovery of etiological factors implicated in the pathogenesis of congenital heart diseases.
\end{abstract}

Keywords: Congenital heart diseases, Long non-coding RNAs, MicroRNAs, Cardiac transcription factor genes, Copy number variants, Signaling pathways

\footnotetext{
* Correspondence: emmanuelsuluba@gmail.com;

emmasulubahenry@yahoo.com

${ }^{1}$ School Basic Medical Sciences, Shandong University, 44 Wenhua Xi Road,

Jinan 250012, Shandong, China

${ }^{2}$ Department of Anatomy and Embryology, Shandong University, 44 Wenhua

Xi Road, Jinan 250012, China

Full list of author information is available at the end of the article
} 


\section{Background}

Congenital heart diseases (CHDs) are the most frequent congenital anomalies among infants and account for approximately 4-10 in 1000 live births [1]. The most common congenital heart defects are ventricular septal defect (VSD), atrial septal defects (ASD), transposition of greater vessels (TGV), patent ductus arteriosus (PDA), and tetralogy of Fallot (TOF) [2]. The prevalence of CHDs varies globally [3-15]. Congenital heart defects are classified clinically, as cyanotic and acyanotic [16]. Bluish discoloration of mucous membrane clinically characterizes cyanotic heart defects due to an increased level of deoxygenated hemoglobin. Therefore, cyanotic congenital heart defects are regarded as the most severe forms of CHDs [17].

Clinical presentations and severity of CHDs depend on their types or sub-types. However, most children with CHDs present with failure to thrive, cough, repeated chest infections, difficulty in breathing, exercise intolerance, and bluish discoloration of mucous membranes (cyanosis) [18]. Congenital heart defects are associated with serious complications such as cognitive impairment [19-27] and often affect families and individuals both emotionally and financially [23, 28-31].

Recent improvements of surgical and diagnostic procedures [32-34] have improved the survival of patients with congenital heart diseases; however, still significant mortalities among infants associated with CHDs are observed [13, 14, 35-37]. The mortality is higher for low birth weight infants even after surgical intervention [38].

Several studies have been conducted to investigate the etiology of CHDs, but the molecular etiology and mechanisms leading to $\mathrm{CHD}$ are still the subject of debate. Nonetheless, advances in molecular techniques give the possibility to study the developmental defects of the heart, thus closing the gap of knowledge between the morphology and genetics [39]. Genetic factors are postulated to play a significant role in the pathogenesis of CHDs [40].

Point mutations of cardiac transcription factor genes, single nucleotide polymorphism (SNPs), aneuploidy, and chromosomal copy number variants $(\mathrm{CNV})$ are directly associated with CHDs [41-43]. Similarly, mutations in genes encoding for receptors and ligands, which are responsible for cardiac morphogenesis signaling pathways such as Notch and Jagged respectively are implicated in the etiology of CHDs [44-46].

Several well-established cardiac transcription factors that are highly expressed in cardiogenic plates such as NKX2.5, GATA4, and TBX5 have been extensively studied in both human [47] and animal experiments [48, 49]. Mutations in these cardiac transcription factors are associated with most non-syndromic CHDs [50]. Functional studies on NKX2.5, GATA4, and TBX5 in animal experiments have indicated high reproducibility of the results
[51], suggesting the monogenic inheritance model of CHD pathogenesis. However, this model (monogenic inheritance) of CHDs pathogenesis raises two important questions; firstly, why do we observe different CHDs phenotypes associated with the same type of single-gene mutations? Secondly, why do we observe the same kind of CHDs phenotypes in different single-gene mutations? These two questions suggest there might be many molecules (multifactorial inheritance) involved in the etiology of CHDs.

Perhaps the most intriguing feature is that the prevalence of the CHDs remains the same notwithstanding the decrease in reproductive potential of the patients with CHDs [52, 53], suggesting that the mutations might not be inherited but rather de novo $[54,55]$. Evolutionarily, we would expect the prevalence of CHDs to be decreasing as the negative selection could have removed the inherited mutation. The reasons for the expected decrease in prevalence being the high mortality rate associated with $\mathrm{CHDs}$ and the decrease in reproductive potential among CHD patients.

The questions also remain if the CHDs mode of inheritance is a familial and whether its mode of inheritance is autosomal dominant or autosomal recessive. This enigma is highlighted by the fact that the autosomal dominant mutation is usually expressed in high penetrance, and we would expect the high percentage of first degree relatives to acquire the CHDs phenotypes, but the study indicates the opposite [56]. The autosomal recessive fashion might be the most appropriate model to define the hereditary bases of CHDs. Studies show that the consanguineous marriages resulted in an increased risk of CHDs [57, 58].

Genomic wide association studies (GWAS) involve the comparison of genetic variants of different affected individuals within the society and whether the variants are associated with a certain trait. GWAS, therefore, can be used to detect multiple genetic risk factors which contribute to congenital heart diseases [59]. CHDs being heterogeneous group of diseases, the use GWAS may give us an insight to the etiology of CHDs [60].

Understanding of the hereditary causes will provide us with an insight to the biological basis of the congenital heart defects; therefore, allow the definition of disease risk, which is the base of disease prevention. It will also illuminate not only the developmental biology of the heart, but also plans for the possibility of future novel treatment of congenital heart diseases. Studying the etiology of CHDs is essential because it may predict clinical outcomes, get to know genetic reproductive risks, and screen for genetic risk factors within the families. Also, it is important to investigate genotype-phenotype correlation as it can provide us with an opportunity to predict the prognosis. Previous studies show that patients with 
CHDs may develop pulmonary hypertension (PHT), and certain types of mutations are associated with its rapid development $[61,62]$. In this case, early intervention is required.

\section{Main text}

\section{Embryogenesis of the heart}

The heart develops from the mesoderm [63]. It is the first organ to develop and starts beating at approximately 22 days of gestation [64]. Its development (embryogenesis) in early days of fetal life involves a series of events which include the following: precardiac cell migration from primitive streak, the formation of 2 primitive heart tubes, fusion of primitive tubes, cardiac looping, cardiac septation, cardiac chamber formation, formation of cardiac conducting system, and the coronary arteries [65-67].

The developmental process of the heart is a tightly regulated process that requires intricate interplay between transcription factors, several cardiac-specific genes, and signaling pathways [68] .Both genetic $[69,70]$ and environmental factors [71] play essential roles during cardiac development. Gene mutations [72] and some teratogens $[73,74]$ can interfere with normal development (embryogenesis) of the heart leading to congenital heart defects.

Endodermal delivered signals such as BMP2, FGF8, crescent, and Shh act as inducers of cardiac mesoderm while inhibitory signals such as chordin, noggin, wnt1, and serrate (ser) are mesodermal delivered [75, 76].

The heart looping, chamber formation, and left to right asymmetry are under the control of cardiogenic plate expressing genes NKX2.5, GATA, HANDS, and TBX5 [77]. During early cardiac development, NKX2.5 [78] and MHC2A [79] genes are essential, and in later stages, MEF2 [80], HAND1, and HAND2 genes [81, 82] are actively transcribed. The regulation process during cardiac development is under the control of transcription factor genes GATA and TBX5, growth factors such as VEGF, FGF, and PDGF, and morphogenic proteins (BMP2, BMP4, BMP5) [79]. Besides, the Foxf genes which control the second heart field in the hedgehog pathway through interaction with TBX are actively involved [83].

\section{Transcription factors genes, cardiac-specific genes, and CHDs}

NKX2.5, GATA4, GATA6, and TBX5 are the most studied transcription factors genes. These genes are the key transcription factors which are involved in early cardiac development $[84,85]$. Studies have revealed mutations and single nucleotide polymorphism (SNPs) in these essential transcription factor genes result in CHDs occurrence [47, 86, 87]. In one large cohort study, they identified the novel mutations in NKX2.5 and GATA4, both mutations were associated with mutations of
MYH6 gene (encoding for cardiac (alpha) myosin), suggesting additive effect to the pathogenesis of CHDs [88]. Mutation in MYH6 is associated with familial atrial septal defect (ASD) [89]. A study among Chinese identified the missense mutations of GATA4 in patients with tetralogy of Fallot and membranous ventral septal defect. They also identified NKX2.5 mutations in patients with isthmus stenosis, ventral septal defect, and patent ductus arteriosus [90].

NKX2.5, a homeodomain transcription factor, is vital in early cardiogenesis in mammals [91]. Mutations in NKX2.5 have been reported in patients with ventral septal defect [92], tetralogy of Fallot, transposition of greater vessels, and patent ductus arteriosus [93], atrial septal defect and hypoplastic left heart syndrome (HLHS) [94]. The association of mutations with clinical manifestations is of paramount importance; NKX2.5 mutation associated ASD was found to present with cardiac conduction defects; thus, patients with mutation in NKX2.5 have an increased risk of cardiac arrest [95]. Overall, more than 40 NKX2.5 transcription factor different mutations have been identified, causing impaired protein function [96] and have a negative impact on transcriptional activity [97].

MEF2C, NKX2.5, GATA4, and GATA6 mutations have been identified in patients with cardiac outflow tract defect (OFT). Studies on the functional analysis have documented significant effect on their protein functions affecting early cardiac development [50]. MEF2C is an essential factor for cardiac development and its loss of function due to mutations results in double outlet ventricle, ventricular septal defects, and patent ductus arteriosus $[98,99]$.

GATA4, a zinc finger transcription factor, is expressed during cardiac development as well as in adult cardiomyocytes [100].GATA4 mutations produce GATA4 protein which reduces cardiomyocytes proliferation in vivo, causing functional deficit [101]. GATA4 mutation is associated with cardioseptal defect [102], some of which are familial [103]. GATA4 mutations were identified in patients with atrial and ventral septal defects but these mutations did not alter the transcriptional activity when combined with other transcription factors such as NKX2.5 and TBX20, suggesting that GATA4, as a single factor may not have a direct effect on the heart by itself [104].

TBX5 transcription factor is an essential regulator in cardiac development [105] as it plays a role in gastrulation process and organogenesis in vertebrates [106]. TBX5 mutation is common in patients with Holt-Oram syndrome, a syndrome which is characterized by skeletal abnormalities and heart diseases [54, 107, 108]. TBX5 mutations were found in patients with tetralogy of Fallot associated with large ostium secundum defect and features of upper limb deformities [109], and also in 
patients with the ventricular septal defects [110]. Some studies indicate that it is not TBX5 mutations that cause CHDs but the abnormality in the TBX5 expression levels is responsible for congenital heart diseases [111].

Mutations in other several genes have been reported to be associated with congenital heart diseases. These genes include the following: ankyrin repeat domain 1 (ANKRD1) associated with septal defects, NR2F2 gene associated with double outlet ventricle, HAND2 gene associated with familial ventral septal defect, pulmonary stenosis, double outlet right ventricle, tetralogy of Fallot, and CASZ1 gene associated with the ventral septal defects [112-116].

Cardiac-specific genes are those genes which encode for cardiac-specific proteins. MYH7 encodes for beta myosin heavy chain and MYH11 encodes for the smooth muscle heavy chain. Mutation in MYH7 is associated with Ebstein anomaly, the condition which is characterized by the fusion of posterior and anterior leaflets of tricuspid valves and left ventricular non-compaction [117]. ACTC is another important gene which encodes for cardiac actin, changes in ACTC due to mutation results into disruption of actin composition of fetal heart leading to severe deficit in both function and structure of the heart $[118,119]$. See summary in Table 1.

\section{MicroRNAs and CHDs}

MicroRNAs (miRNAs) are small non-coding RNA molecules (18 26 nucleotides) that regulate eukaryotic gene expression at the post-transcription level [120]. The microRNAs blocks gene expression by interacting with the 3UTR region of the messenger RNA [121]. They act as gene suppressors by inhibiting messenger RNA translation or cause the degradation of messenger RNA. MicroRNAs cause the RNA strand cleavage, shortening of polyA tail of messenger RNA, and making the messenger RNA less efficient to be translated by ribosomes [122].

A single microRNA has an ability to interfere with multiple target genes; thus, perturb the entire network, which can eventually result in a serious pathological state [123]. miRNA exerts its canonical repressive effect by binding to Argonaute (AGO) proteins [124]. Recent studies have shown that miRNA can bind to other nonAGO RNA-binding proteins. miR-328 has been found to bind to heterogeneous nuclear ribonucleoproteins (rhnRNPE2) within the CCAAT Enhancer Binding Protein Alpha (CEBPA) of mRNA mediating transcriptional inhibition [125].

Apart from interfering with the messenger RNA by its repressive activity, the miRNAs have other unconventional roles. These roles include up regulation of protein expression upon cell cycle arrest [126] and target mitochondrial transcript by inhibiting cytochrome c-oxidase subunit (MT-COX I). In this case, miRNA-181c translocates into the mitochondria and exerts its action by enhancing (MT-COX 2) mRNA expression through miRNA-181c binding [127]. miRNAs can also activate Toll receptor (TLR). TLR plays a crucial role in innate immunity. Let-7 has been found to activate TLR7 causing neurodegeneration [128].

miRNAs play a crucial role in cardiac morphogenesis with regards to patterning, proliferation, and differentiation of myocardium [129]. Therefore, microRNAs are important therapeutic target and potential in regenerative medicine [130]. We can use miRNAs as biomarkers for the diagnosis of congenital heart diseases [131], for instance, miR-499 is regarded as a useful biomarker for congenital heart disease diagnosis [132]. miRNAs are significantly upregulated, and target genes that are important for cardiac development such as TBX5 gene [133] and NOTCH 1, HAND1, and GATA3 genes which

\begin{tabular}{|c|c|c|}
\hline $\begin{array}{l}\text { Candidate } \\
\text { gene }\end{array}$ & CHD phenotype & References \\
\hline NKX2.5 & $\begin{array}{l}\text { Tetralogy of Fallot, patent ductus arteriosus, transposition of greater vessels, atrial septal defects with conduction defects, } \\
\text { and hypoplastic left heart syndrome }\end{array}$ & [93-95] \\
\hline MEF2C & Double outlet ventricle, ventricular septal defects, and patent ductus arteriosus & {$[98,99]$} \\
\hline GATA4 & Atrial and ventral septal defects & {$[102,104]$} \\
\hline TBX5 & Holt-Oram syndrome, ostium secondum defects, tetralogy of Fallot, and ventricular septal defects & {$[109,110]$} \\
\hline ANKRD1 & Septal defects & {$[113]$} \\
\hline NR2F2 & Double outlet ventricle & [112] \\
\hline HAND2 & Familial ventral septal defect, pulmonary stenosis, double outlet ventricle, and tetralogy of Fallot & [115] \\
\hline CASZ1 & Ventral septal defects & {$[114]$} \\
\hline MYH6 & Familial atrial septal defects & {$[89]$} \\
\hline MYH7 & Ebstein anomaly and left ventricular non-compaction & {$[117]$} \\
\hline
\end{tabular}


are vital for the right ventricle development [134]. miRNA dysregulation is known to cause severe congenital anomaly of the heart such as hypoplastic left heart [135], a condition which is largely characterized by maldevelopment of the right side of the heart.

miRNA normally interact with the 3UTR site of the gene; thus, a single nucleotide polymorphism to the 3UTR site of cardiac transcription factor gene GATA4 is associated with congenital heart disease [136].miRNA145 targets the FXN gene (gene making a protein frataxin, which is abundant in the heart) by negatively regulating its function through apoptosis and mitochondrial function [137]. The downregulation of miRNA$199 a-5 p$ favors the unfolded protein response, thus protecting the myocardium against hypoxia-induced endoplasmic reticulum stress in patients with congenital heart disease and mechanistically by binding to GTP78 and ATP 6 changing their gene expression [138].

miRNA-84 has been found to be significantly downregulated and associated with cyanotic congenital heart diseases; miRNA-84 decreases proliferation and increases the apoptosis of cardiomyocytes [139]. In a different study, it has been demonstrated that miRNA-1 promotes cardiomyocyte proliferation through activation of HANDS2 (a key gene which is involved in cardiac development) and suppression of apoptosis by decreasing the caspase 3-cleavage [140]. The roles of these small non-coding RNAs are stressed in a study which found miRNA-499 single nuclear polymorphism to be associated with congenital heart diseases. miRNA-499 inhibits the expression of methionine synthase (MTR), a key enzyme in folate metabolism, thus interfering with early development of the heart [141]. Which specific miRNAs are upregulated or downregulated in different types of CHDs and mechanisms on how miRNAs cause CHDs is still elusive. High throughput miRNA sequencing in malformed heart will provide insight to the novel miRNAs, which are essential in cardiac morphogenesis.

\section{Long non-coding RNAs and CHDs}

Long non-coding RNAs (LncRNAs) are made up of more than 200 nucleotides with no coding function and they are actively transcribed in metazoans [142]. LncRNAs have been reported to play various biological processes by controlling gene expression through histone modifications or epigenetics [143]. LncRNAs are linked to the development of congenital heart diseases, and therefore can be used as the potential biomarkers for prediction of occurrence of fetal CHD in pregnant mothers [144].

Post-transcriptional regulation during cardiac embryogenesis is an essential part of normal cardiac development [145]. Long non-coding RNA and miRNAs have been implicated to play an indispensable role during cardiac development by influencing gene expression and post-transcription regulation [146]. Indeed long coding RNAs are essential in the regulation of mammalian cardiac morphogenesis and play a role in pathogenesis of cardiac tissue diseases [147].

Dysregulation of LncRNA in cardiac tissue was found among patients with VSDs which indicates that there is an association between LncRNA and congenital heart diseases [148]. Aberrant expression of LnRNAs was found in pregnant mothers with fetal congenital heart diseases which designate that LnRNAs play a significant role in the development of congenital heart disease [144]. LncRNA uc 4 over expression inhibits the TGF- $\beta$ signaling pathway resulting in the development of congenital heart diseases [149]. Long non-coding RNAs play a role in controlling the transcription of HANDS 2 which plays an important role in guiding cardiac morphogenesis [115], therefore blocking the transcription of long non-coding RNA (Uph) and results in right ventricular hypoplasia and early embryonic lethality in mice [150].

\section{Chromosomal abnormalities, copy number variants, and CHDs}

Congenital heart defects are the most common congenital malformations found among patients with chromosomal aberrations. Studies have shown that congenital heart defects are associated with some forms of chromosomal abnormalities. The commonest form of aneuploidy, the Down syndrome (trisomy 21), is usually associated with atrial septal defect (ASDs) [151, 152]. The abnormalities in chromosomal number (aneuploidy) are often associated with an increased risk of congenital heart diseases. Many different cardiac phenotypes are associated with aneuploidy. About $50 \%$ of patients with trisomy 21 and Turner's syndrome $(45, \quad \mathrm{X})$ develop congenital heart diseases, and in Turner's syndrome premature mortality is caused by CHDs complications [153, 154]. In the case of other trisomies such as trisomy 18 and trisomy 13, the prevalence of CHDs is more than $50 \%$ of the cases [155].

Children with congenital heart defects have a high incidence of pathological copy number variants [156], implying that subtle chromosomal changes (copy number variants) play an essential role in the etiology of congenital heart defects. It is, therefore, necessary to find out the copy number variants as it can give us an insight to the etiology of CHDs [157].

Karyotyping and chromosomal microarray (CMA) methods have been used to identify the number of abnormal chromosomes and copy number variants (CMV), respectively [158-160]. These methods are used widely for the diagnosis of fetal aneuploidy. Prenatal diagnosis using these technologies can help to predict the fetal outcomes. Recently, the chromosomal microarrays and 
next generation sequencing are reliable tools for investigating the genetic abnormalities in patients with congenital heart diseases $[161,162]$. We can also identify the copy number variants in a specific genomic region by multiplex ligation-independent probe amplification $[156,163]$ and its modified form which is known for its high sensitivity and specificity [164].

CMA and karyotyping are the two screening methods which can supplement each other, and thus, negative karyotyping results should be re-examined by using chromosomal microarrays [165]. Studies have associated the occurrence of copy number variants and congenital heart diseases $[166,167]$ and other malformations such as that of limbs [168]. Copy number variants (microdeletion) were found in VSD patients with normal karyotyping results [169]. Therefore, it is vital to have CMA even in a fetus with normal karyotype.

Chromosomal microarrays (CMA) can be used to detect the pathological CNVs in patients with CHDs. The detection of pathogenic CNVs in syndromic CHD patients using CMA has been found to have the diagnostic yield of up to $20 \%$ [170]. CMA can detect both pathological $\mathrm{CNV}$ and those $\mathrm{CNV}$ of unknown significance (VOUS) [171]. Copy number variant (gene deletion and duplications) was found in a patient with heterotaxy, functional analysis on the variant genes revealed that the genes are involved in left to right patterning of the heart [172]. Microdeletion and microduplication are highly implicated in pathogenesis of CHDs, $240 \mathrm{CNVs}$ were found in genes which are involved in cardiac development including, NRP1, NTRK3, MESP1, ADAM19, and HAND1 [173].

A cohort study found that the gain of more than 200 $\mathrm{kb}$ or losses of $100 \mathrm{~kb}$ in different cardiac-specific genes was associated with $\mathrm{CHDs}$; significant enrichment were found in patients with tetralogy of Fallot, atrial ventricular septal defect, truncus arteriosus, subaortic stenosis, and atrial ventricular canal [174]. In patients with Down syndrome, not only the chromosomal number abnormalities are implicated in causing CHDs, but also the combination of copy number variants and single nucleotide polymorphism in certain specific genes may be found in the same chromosome. Another cohort study found that rs2832616 and rs1943950 SNPs and CNV in RIPK4 and ZBTB21 genes within chromosome 21 in a Down syndrome patient, suggesting multiple gene aberrations [175]. 22q11 deletion, 17p13.3, 4q35, and TBX1 deletions are highly associated with conotruncal defect abnormalities [176] and $3.76 \mathrm{Mb}$ de novo gain of 9q34.2q34.3 is associated with tetralogy of Fallot with the absence of pulmonary valve [177]. In addition, serious cardiac malformations have been documented due to duplication and deletion in GATA4 and SOX7 genes respectively [178] as well as in NODAL gene [179].

\section{Signaling pathways and CHDs}

Cardiogenesis is a complex process which requires early cardiac stem cell fate, proliferation differentiation, and organ formation. It is therefore important for the developing embryo to tightly regulate these processes through signaling pathways. Early normal cardiac morphogenesis depends on perfect regulation of signaling pathways, and thus, during cardiac development intracellular crosstalk is important for spatial-temporal precision [68]. During the development of the heart, Notch signaling, BMP, and TGF- $\beta$ are critical pathways; they work together to promote epithelial-mesenchymal transition (EMT) as well as mesenchyme cell invasiveness [180].

NOTCH signaling pathway is a highly conserved pathway which plays an important role in early cardiac development; it is therefore important for ultimate cellular development, differentiation, proliferation, apoptosis, adhesion, and epithelial-mesenchymal transition [181]. Thus, cardiac progenitor cell ability to differentiate from the mesoderm to mature cardiomyocytes is under the control of the $\mathrm{NOTCH}$ signaling pathway. $\mathrm{NOTCH}$ is also crucial for the repair of mature cardiomyoctes after myocardial injury [125] and protects the heart from hypertrophic responses as well as the survival of cardiomyocytes [182]. Notch receptor interacts with the endocardium and neurocrest cells forming signals to regulate the morphogenesis of the heart, in particular, the formation of the endocardium during chamber and valve development as well as during valve formation. $\mathrm{NOTCH}$ signaling pathway promotes epithelial-mesenchymal transition and controls endocardium-myocardium signals leading to the formation of trabecular myocytes [183]. NOTCH signaling pathway also participates in outflow tract formation and trabecular compaction [184]. It is, therefore, essential to understand that any perturbation in this important signaling pathway may cause congenital heart disease.

Animal experiments have revealed that mutations of $\mathrm{NOTCH}$ receptor and ligands can lead to several different types of congenital malformations including the congenital heart defects. NOTCH 1 receptor and its ligands jagged 1 mutations are associated with congenital heart defects [185]. Alterations of the NOTCH signaling pathway lead to abnormal ventricular chamber development, non-compaction, and cardiomyopathy [186]. Novel mutations of NOTCH 1 have been identified in patients with severe forms of congenital heart disease, the hypoplastic left heart syndrome (HLHS) [187].

A study has shown that the induced pluripotent stem cells generated from the patient with hypoplastic left heart syndrome when allowed to differentiate into mature cardiomyocytes in vitro, show reduced NOTCH receptor expression, disorganization of sarcomere, and low beating rate [188]. Also, in the same study, they found 
that the activation of $\mathrm{NOTCH}$ receptor through jagged ligand interaction restores the cardiomyocytes' ability to differentiate and beating rate as well as reduces smooth muscle formation [188]. iPCs generated from the HLHS show reduced expression of NKX2-5, TBX2, and $\mathrm{NOTCH}$ genes with a consequent decrease in their differentiation potential. Co-transfection with these promoters restores the potential of cells to differentiate [189].

TGF- $\beta$ signaling pathway has been found to play an essential part in the development of embryonic myocardium. Mutation in TBX20 transcription factor gene causes abnormal signaling of TGF- $\beta$ pathway in induced pluripotent stem cells delivered from left ventricular non-compaction cardiomyopathy [190]. $\beta 2$-spectrin is an adaptor of Smads and it plays an important role in TGF$\beta$ signaling pathway. Animal experiments have found that $\beta 2$-spectrin loss leads to inactivation of TGF- $\beta$ signaling and developmental defects of the heart, particularly affecting the ventricular wall [191].

\section{Non-inherited risk factors and CHDs}

Most studies have been done on genetic risk factors and their association with congenital heart defects, therefore giving us the way to define disease risk. However, little information is available for the modifiable risk factors associated with congenital heart defects. Studies have shown non-inherited risk factors are associated with congenital heart defects. During the embryonic period, which normally ends at 8 weeks of gestation, mothers are advised to avoid substances that are deemed as teratogens [192, 193]. Advanced maternal age has been implicated to the etiology of congenital heart diseases possibly because age increases the chances of chromosomal aberrations; however, little evidence is available with regard to advanced maternal age in the absence of chromosomal abnormality [194, 195].

There is a strong correlation between drug exposure, viral infection, and conotruncal defects [196]. Congenital rubella infection is a risk factor for many malformations including the CHDs [197, 198]. Smoking during pregnancy has been found to increase the risk of congenital heart defects $[199,200]$ and women who smoke cigarettes have a substantial possibility of having children with atrial septal defects [201]. Maternal obesity is associated with increased risk of birth defects [202] and pregestational high body mass index has been found to be a risk factor for CHD development, particularly the left and right ventricular outflow tracts, septal defects, and hypoplastic left heart syndrome [203, 204]. Maternal hyperglycemia is also an important risk factor implicated to CHDs [205]. Besides, folic acid intake has been associated with many congenital defects but many studies have indicated that there is no association of folic acid intake and CHDs [206-208]. With all these environmental factors implicated, in causing CHDs, it is therefore reasonable to say both genetic and environmental factors are being associated with congenital heart defects [209].

\section{Conclusions}

The etiology congenital heart disease is a diverse and interesting area of the study. CHD multifactorial etiology imposes a challenge in defining its pathogenesis. Large genomic wide association studies (GWAS), welldesigned studies on non-inherited risk factors, and use of contemporary technologies such as high throughput sequencing may eventually pave away for understanding the genetic and non-genetic causes of congenital heart diseases.

\section{Abbreviations}

ASD: Atrial septal defects; CHDs: Congenital heart diseases; CMA: Chromosomal microarrays; CNV: Copy number variants; GWAS: Genomic wide association studies; HLHS: Hypoplastic left heart syndrome; LncRNAs: Long non-coding RNAs; miRNAS: MicroRNAs; PDA: Patent ductus arteriosus; PHT: Pulmonary hypertension; SNPs: Single nucleotide polymorphism; TGV: Transposition of greater vessels; TOF: Tetralogy of Fallot; VOUS: Variations of unknown significance; VSD: Ventricular septal defect

\section{Acknowledgements}

We thank the University of Shandong for providing facilities required for effective writing and submitting the article for publication.

\section{Authors' contributions}

All authors did participate in the whole process of writing a review. ES contributed the concept, manuscript drafting, manuscript writing, and literature review. LS provided the guidelines, manuscript corrections, and supervision. QX did the literature review and manuscript writing. AM did the reference sorting and writing the manuscript. All the authors have read and approved the manuscript.

\section{Funding}

Chinese Government Scholarship (CSC), funded by the Government of China.

\section{Availability of data and materials}

All the data and publications used as references in this review were cited from PubMed. We used the Endnote software version 8 for data management and referencing

\section{Ethics approval and consent to participate}

Not applicable

\section{Consent for publication}

Consent to publish the review was provided by the Department of Anatomy, School of Basic Sciences, Shandong University.

\section{Competing interests}

The authors declare that they have no competing interests.

\section{Author details}

'School Basic Medical Sciences, Shandong University, 44 Wenhua Xi Road, Jinan 250012, Shandong, China. ${ }^{2}$ Department of Anatomy and Embryology, Shandong University, 44 Wenhua Xi Road, Jinan 250012, China. ${ }^{3}$ School of Medicine, Shandong University, 44 Wenhua Xi Road, Jinan 250012,

Shandong, China. 
Received: 21 October 2019 Accepted: 5 February 2020

Published online: 28 February 2020

\section{References}

1. Miranovic V (2014) The incidence of congenital heart disease: previous findings and perspectives. Srp Arh Celok Lek 142(3-4):243-248

2. van der Bom T, Zomer AC, Zwinderman AH, Meijboom FJ, Bouma BJ, Mulder BJ (2011) The changing epidemiology of congenital heart disease. Nat Rev Cardiol 8(1):50-60

3. Bhardwaj R, Rai SK, Yadav AK, Lakhotia S, Agrawal D, Kumar A et al (2015) Epidemiology of congenital heart disease in India. Congenital Heart Dis. 10(5):437-446

4. Wei YJ, Liu BM, Zhou YH, Jia XH, Mu SG, Gao XR et al (2014) Spectrum and features of congenital heart disease in Xi'an, China as detected using fetal echocardiography. Genet Mol Res 13(4):9412-9420

5. Bhat NK, Dhar M, Kumar R, Patel A, Rawat A, Kalra BP (2013) Prevalence and pattern of congenital heart disease in Uttarakhand, India. Indian J Pediatr 80(4):281-285

6. Nazari P, Davoodi M, Faramarzi M, Bahadoram M, Dorestan N (2016) Prevalence of congenital heart disease: a single center experience in southwestern of Iran. Glob J Health Sci 8(10):56421

7. Sadoh WE, Uzodimma CC, Daniels Q (2013) Congenital heart disease in Nigerian children: a multicenter echocardiographic study. World J Pediatr Congenit Heart Surg 4(2):172-176

8. Liu F, Yang YN, Xie X, Li XM, Ma X, Fu ZY et al (2015) Prevalence of congenital heart disease in Xinjiang multi-ethnic region of China. PLoS One 10(8):e0133961

9. Mohammad N, Shaikh S, Memon S, Das H (2014) Spectrum of heart disease in children under 5 years of age at Liaquat University Hospital, Hyderabad, Pakistan. Indian Heart J 66(1):145-149

10. Hoffman Jl, Kaplan S (2002) The incidence of congenital heart disease. J Am Coll Cardiol 39(12):1890-1900

11. Egbe A, Uppu S, Lee S, Stroustrup A, Ho D, Srivastava S (2015) Temporal variation of birth prevalence of congenital heart disease in the United States. Congenit Heart Dis 10(1):43-50

12. Tankeu AT, Bigna JJ (2017) Prevalence and patterns of congenital heart diseases in Africa: a systematic review and meta-analysis protocol. BMJ Open 7(2):e015633

13. Dolk H, Loane M, Garne E (2011) Congenital heart defects in Europe: prevalence and perinatal mortality, 2000 to 2005. Circulation. 123(8):841-849

14. Abid D, Elloumi A, Abid L, Mallek S, Aloulou H, Chabchoub I et al (2014) Congenital heart disease in 37,294 births in Tunisia: birth prevalence and mortality rate. Cardiol Young 24(5):866-871

15. Yeh SJ, Chen HC, Lu CW, Wang JK, Huang LM, Huang SC et al (2013) Prevalence, mortality, and the disease burden of pediatric congenital heart disease in Taiwan. Pediatr Neonatol 54(2):113-118

16. Rohit M, Shrivastava S (2018) Acyanotic and cyanotic congenital heart diseases. Indian J Pediatr 85(6):454-460

17. Ratti C, Veronesi B, Grassi L, Bompani B (2012) Congenital heart diseases in clinical practice. Recenti Progressi Med 103(5):213-217

18. Garcia RU, Peddy SB (2018) Heart disease in children. Primary Care 45(1): 143-154

19. Brunmeier A, Reis MP, Earing MG, Umfleet $L$, Ginde $S$ (2018) Identifying selfreported neurocognitive deficits in the adult with congenital heart disease using a simple screening tool. Congenit Heart Dis 13(5):728-733

20. Sanz JH, Berl MM, Armour AC, Wang J, Cheng YI, Donofrio MT (2017) Prevalence and pattern of executive dysfunction in school age children with congenital heart disease. Congenital Heart Dis 12(2):202-209

21. Klouda L, Franklin WJ, Saraf A, Parekh DR, Schwartz DD (2017) Neurocognitive and executive functioning in adult survivors of congenital heart disease. Congenital Heart Dis 12(1):91-98

22. Ilardi D, Ono KE, McCartney R, Book W, Stringer AY (2017) Neurocognitive functioning in adults with congenital heart disease. Congenital Heart Dis 12(2):166-173

23. Almesned S, Al-Akhfash A, Mesned AA (2013) Social impact on families of children with complex congenital heart disease. Ann Saudi Med 33(2):140-143

24. Marino BS, Lipkin PH, Newburger JW, Peacock G, Gerdes M, Gaynor JW et al (2012) Neurodevelopmental outcomes in children with congenital heart disease: evaluation and management: a scientific statement from the American Heart Association. Circulation. 126(9):1143-1172
25. Lata K, Mishra D, Mehta V, Juneja M (2015) Neurodevelopmental status of children aged 6-30 months with congenital heart disease. Indian Pediatr 52(11):957-960

26. Matos SM, Sarmento S, Moreira S, Pereira MM, Quintas J, Peixoto B et al (2014) Impact of fetal development on neurocognitive performance of adolescents with cyanotic and acyanotic congenital heart disease. Congenit Heart Dis 9(5):373-381

27. Tyagi M, Fteropoulli T, Hurt CS, Hirani SP, Rixon L, Davies A et al (2017) Cognitive dysfunction in adult CHD with different structural complexity. Cardiol Young 27(5):851-859

28. Kim J, Cha C (2017) Experience of fathers of neonates with congenital heart disease in South Korea. Heart Lung 46(6):439-443

29. Kovacs AH, Moons P (2014) Psychosocial functioning and quality of life in adults with congenital heart disease and heart failure. Heart Fail Clin 10(1):35-42

30. Gupta S, Giuffre RM, Crawford S, Waters J (1998) Covert fears, anxiety and depression in congenital heart disease. Cardiol Young 8(4):491-499

31. Bevilacqua F, Palatta S, Mirante N, Cuttini M, Seganti G, Dotta A et al (2013) Birth of a child with congenital heart disease: emotional reactions of mothers and fathers according to time of diagnosis. J Matern Fetal Neonatal Med 26(12):1249-1253

32. McLaughlin ES, Schlosser BA, Border WL (2016) Fetal diagnostics and fetal intervention. Clin Perinatol 43(1):23-38

33. Muthialu N (2018) Orthotopic heart transplantation in children. Asian Cardiovasc Thorac Ann 26(4):277-284

34. Ohye RG, Bove EL (2001) Advances in congenital heart surgery. Curr Opin Pediatr 13(5):473-481

35. Perez-Lescure Picarzo J, Mosquera Gonzalez M, Latasa Zamalloa P, Crespo MD (2018) Congenital heart disease mortality in Spain during a 10 year period (2003-2012). Anales de pediatria 88(5):273-279

36. Polito A, Piga S, Cogo PE, Corchia C, Carnielli V, Da Fre M et al (2013) Increased morbidity and mortality in very preterm/NLBW infants with congenital heart disease. Intensive Care Med 39(6):1104-1112

37. Marantz P, Saenz Tejeira MM, Pena G, Segovia A, Fustinana C (2013) Fetal and neonatal mortality in patients with isolated congenital heart diseases and heart conditions associated with extracardiac abnormalities. Arch Argentinos de pediatria 111(5):418-422

38. Ades AM, Dominguez TE, Nicolson SC, Gaynor JW, Spray TL, Wernovsky G et al (2010) Morbidity and mortality after surgery for congenital cardiac disease in the infant born with low weight. Cardiol Young 20(1):8-17

39. Calcagni G, Unolt M, Digilio MC, Baban A, Versacci $P$, Tartaglia M et al (2017) Congenital heart disease and genetic syndromes: new insights into molecular mechanisms. Expert Rev Mol Diagn 17(9):861-870

40. Pierpont ME, Brueckner M, Chung WK, Garg V, Lacro RV, McGuire AL et al (2018) Genetic basis for congenital heart disease: revisited: a scientific statement from the American Heart Association. Circulation. 138(21):e653-e711

41. Soemedi R, Wilson IJ, Bentham J, Darlay R, Topf A, Zelenika D et al (2012) Contribution of global rare copy-number variants to the risk of sporadic congenital heart disease. Am J Hum Genet 91(3):489-501

42. Chen LT, Yang TB, Wang TT, Zheng Z, Zhao L, Ye ZW et al (2018) Association of single nucleotide polymorphisms of transcription factors with congenital heart diseases in the Chinese population: a meta analysis. Zhongguo dang dai er ke za zhi 20(6):490-496

43. Su W, Zhu P, Wang R, Wu Q, Wang M, Zhang X et al (2017) Congenital heart diseases and their association with the variant distribution features on susceptibility genes. Clin Genet 91(3):349-354

44. McBride KL, Riley MF, Zender GA, Fitzgerald-Butt SM, Towbin JA, Belmont JW et al (2008) NOTCH1 mutations in individuals with left ventricular outflow tract malformations reduce ligand-induced signaling. Hum Mol Genet 17(18):2886-2893

45. Safari-Arababadi A, Behjati-Ardakani M, Kalantar SM, Jaafarinia M (2018) Silencing mutations in JAG1 gene may play crucial roles in the pathogenesis of tetralogy of Fallot. Cell Mol Biol 64(4):103-107

46. Digilio MC, Luca AD, Lepri F, Guida V, Ferese R, Dentici ML et al (2013) JAG1 mutation in a patient with deletion 22q11.2 syndrome and tetralogy of Fallot. Am J Med Genet Part A 161a(12):3133-3136

47. Behiry EG, Al-Azzouny MA, Sabry D, Behairy OG, Salem NE (2019) Association of NKX2-5, GATA4, and TBX5 polymorphisms with congenital heart disease in Egyptian children. Mol Genet Genomic Med. 7(5):e612

48. Han H, Chen Y, Liu G, Han Z, Zhao Z, Tang Y (2015) GATA4 transgenic mice as an in vivo model of congenital heart disease. Int J Mol Med 35(6):1545-1553 
49. Andersen TA, Troelsen Kde L, Larsen LA (2014) Of mice and men: molecular genetics of congenital heart disease. Cell Mol Life Sci 71(8):1327-1352

50. Kodo K, Nishizawa T, Furutani M, Arai S, Ishihara K, Oda M et al (2012) Genetic analysis of essential cardiac transcription factors in 256 patients with non-syndromic congenital heart defects. Circ J 76(7):1703-1711

51. Zakariyah AF, Rajgara RF, Veinot JP, Skerjanc IS, Burgon PG (2017) Congenital heart defect causing mutation in Nkx2.5 displays in vivo functional deficit. J Mol Cell Cardiol 105:89-98

52. Radford DJ, Stafford G (2005) Pregnancy and the Rastelli operation. Aust N Z J Obstetr Gynaecol 45(3):243-247

53. Drenthen W, Pieper PG, Roos-Hesselink JW, van Lottum WA, Voors AA Mulder BJ et al (2007) Outcome of pregnancy in women with congenital heart disease: a literature review. J Am Coll Cardiol 49(24):2303-2311

54. Rios-Serna LJ, Diaz-Ordonez L, Candelo E, Pachajoa H (2018) A novel de novo TBX5 mutation in a patient with Holt-Oram syndrome. Appl Clin Genet 11:157-162

55. Guo J, Li Z, Hao C, Guo R, Hu X, Qian S et al (2019) A novel de novo CASZ1 heterozygous frameshift variant causes dilated cardiomyopathy and left ventricular noncompaction cardiomyopathy. Mol Genet Genomic Med 7(8):e828

56. Oyen N, Poulsen G, Boyd HA, Wohlfahrt J, Jensen PK, Melbye M (2009) Recurrence of congenital heart defects in families. Circulation. 120(4):295-301

57. Mani A, Meraji SM, Houshyar R, Radhakrishnan J, Mani A, Ahangar M et al (2002) Finding genetic contributions to sporadic disease: a recessive locus at 12q24 commonly contributes to patent ductus arteriosus. Proc National Acad Sci USA 99(23):15054-15059

58. Shieh JT, Bittles AH, Hudgins L (2012) Consanguinity and the risk of congenital heart disease. Am J Med Genet Part A 158a(5):1236-1241

59. Jiang T, Huang M, Jiang T, Gu Y, Wang Y, Wu Y et al (2018) Genome-wide compound heterozygosity analysis highlighted 4 novel susceptibility loci for congenital heart disease in Chinese population. Clinical Genet 94(3-4):296-302

60. Agopian AJ, Goldmuntz E, Hakonarson H, Sewda A, Taylor D, Mitchell LE (2017) Genome-wide association studies and meta-analyses for congenital heart defects. Circ Cardiovasc Genet 10(3):e001449

61. Beghetti M, Tissot C (2009) Pulmonary arterial hypertension in congenital heart diseases. Semin Respir Crit Care Med 30(4):421-428

62. Roberts KE, McElroy JJ, Wong WP, Yen E, Widlitz A, Barst RJ et al (2004) BMPR2 mutations in pulmonary arterial hypertension with congenital heart disease. Eur Respir J 24(3):371-374

63. Miquerol L, Kelly RG (2013) Organogenesis of the vertebrate heart. Wiley Interdiscip Rev Dev Biol 2(1):17-29

64. Sylva M, van den Hoff MJ, Moorman AF (2014) Development of the human heart. Am J Med Genet Part A 164a(6):1347-1371

65. Kloesel B, DiNardo JA, Body SC (2016) Cardiac embryology and molecular mechanisms of congenital heart disease: a primer for anesthesiologists. Anesth Analg 123(3):551-569

66. Schleich JM, Abdulla T, Summers R, Houyel L (2013) An overview of cardiac morphogenesis. Arch Cardiovasc Dis 106(11):612-623

67. Sedmera D, McQuinn T (2008) Embryogenesis of the heart muscle. Heart Fail Clin 4(3):235-245

68. MacGrogan D, Munch J, de la Pompa JL (2018) Notch and interacting signalling pathways in cardiac development, disease, and regeneration. Nat Rev Cardiol 15(11):685-704

69. Cowan JR, Ware SM (2015) Genetics and genetic testing in congenital heart disease. Clin Perinatol 42(2):373-393 ix

70. Arrington CB, Bleyl SB, Brunelli L, Bowles NE (2013) Family-based studies to identify genetic variants that cause congenital heart defects. Futur Cardiol 9(4):507-518

71. Nicoll R (2018) Environmental Contaminants and Congenital Heart Defects: A Re-Evaluation of the Evidence. Int J Environ Res Pub Health 15(10):2096

72. Dianatpour S, Khatami M, Heidari MM, Hadadzadeh M (2019) Novel point mutations of CITED2 gene are associated with non-familial congenital heart disease (CHD) in sporadic pediatric patients. Appl Biochem Biotechnol. https://doi.org/10.1007/s12010-019-03125-8. Printed online 13 Sept 2019.

73. Liu Q, Van Bortle K, Zhang Y, Zhao MT, Zhang JZ, Geller BS et al (2018) Disruption of mesoderm formation during cardiac differentiation due to developmental exposure to 13-cis-retinoic acid. Sci Rep 8(1):12960

74. Khalil A, Tanos R, El-Hachem N, Kurban M, Bouvagnet P, Bitar F et al (2017) A HAND to TBX5 explains the link between thalidomide and cardiac diseases. Sci Rep 7(1):1416

75. Brand T (2003) Heart development: molecular insights into cardiac specification and early morphogenesis. Dev Biol 258(1):1-19
76. Cohen ED, Tian Y, Morrisey EE (2008) Wnt signaling: an essential regulator of cardiovascular differentiation, morphogenesis and progenitor self-renewal. Development 135(5):789-798

77. Huang JB, Liu YL, Sun PW, Lv XD, Du M, Fan XM (2010) Molecular mechanisms of congenital heart disease. Cardiovasc Pathol 19(5):e183-e193

78. Zhang L, Nomura-Kitabayashi A, Sultana N, Cai W, Cai X, Moon AM et al (2014) Mesodermal Nkx2.5 is necessary and sufficient for early second heart field development. Developmental Biol 390(1):68-79

79. Kobylinska J, Dworzanski W, Cendrowska-Pinkosz M, Dworzanska A, Hermanowicz-Dryka T, Kiszka J et al (2013) Morphological and molecular bases of cardiac development. Postepy Hig Med Dosw 67:950-957

80. Materna SC, Sinha T, Barnes RM, Lammerts van Bueren K, Black BL (2019) Cardiovascular development and survival require Mef2c function in the myocardial but not the endothelial lineage. Dev Biol 445(2):170-177

81. Vincentz JW, Barnes RM, Firulli AB (2011) Hand factors as regulators of cardiac morphogenesis and implications for congenital heart defects. Birth Defects Res Clin Mol Teratol 91(6):485-494

82. Morikawa Y, Cserjesi P (2008) Cardiac neural crest expression of Hand2 regulates outflow and second heart field development. Circ Res 103(12): $1422-1429$

83. Hoffmann AD, Yang $X H$, Burnicka-Turek O, Bosman JD, Ren $X$, Steimle JD et al (2014) Foxf genes integrate tbx5 and hedgehog pathways in the second heart field for cardiac septation. PLoS Genet 10(10):e1004604

84. McCulley DJ, Black BL (2012) Transcription factor pathways and congenital heart disease. Curr Top Dev Biol 100:253-277

85. Maitra M, Schluterman MK, Nichols HA, Richardson JA, Lo CW, Srivastava D et al (2009) Interaction of Gata4 and Gata6 with Tbx5 is critical for normal cardiac development. Dev Biol 326(2):368-377

86. Mori AD, Bruneau BG (2004) TBX5 mutations and congenital heart disease: Holt-Oram syndrome revealed. Curr Opin Cardiol 19(3):211-215

87. Chen HX, Zhang X, Hou HT, Wang J, Yang Q, Wang XL et al (2017) Identification of a novel and functional mutation in the TBX5 gene in a patient by screening from 354 patients with isolated ventricular septal defect. Eur J Med Genet 60(7):385-390

88. Granados-Riveron JT, Pope M, Bu'lock FA, Thornborough C, Eason J, Setchfield K et al (2012) Combined mutation screening of NKX2-5, GATA4, and TBX5 in congenital heart disease: multiple heterozygosity and novel mutations. Congenit Heart Dis 7(2):151-159

89. Ching YH, Ghosh TK, Cross SJ, Packham EA, Honeyman L, Loughna S et al (2005) Mutation in myosin heavy chain 6 causes atrial septal defect. Nat Genet 37(4):423-428

90. Peng T, Wang L, Zhou SF, Li X (2010) Mutations of the GATA4 and NKX2.5 genes in Chinese pediatric patients with non-familial congenital heart disease. Genet. 138(11-12):1231-1240

91. Zhu W, Shiojima I, Hiroi Y, Zou Y, Akazawa H, Mizukami M et al (2000) Functional analyses of three Csx/Nkx-2.5 mutations that cause human congenital heart disease. J Biol Chem 275(45):35291-35296

92. Pang S, Shan J, Qiao Y, Ma L, Qin X, Wanyan H et al (2012) Genetic and functional analysis of the NKX2-5 gene promoter in patients with ventricular septal defects. Pediatr Cardiol 33(8):1355-1361

93. McElhinney DB, Geiger E, Blinder J, Benson DW, Goldmuntz E (2003) NKX2.5 mutations in patients with congenital heart disease. J Am Coll Cardiol 42(9): 1650-1655

94. Elliott DA, Kirk EP, Yeoh T, Chandar S, McKenzie F, Taylor P et al (2003) Cardiac homeobox gene NKX2-5 mutations and congenital heart disease: associations with atrial septal defect and hypoplastic left heart syndrome. J Am Coll Cardiol 41(11):2072-2076

95. Ellesoe SG, Johansen MM, Bjerre JV, Hjortdal VE, Brunak S, Larsen LA (2016) Familial atrial septal defect and sudden cardiac death: identification of a novel NKX2-5 mutation and a review of the literature. Congenit Heart Dis 11(3):283-290

96. Reamon-Buettner SM, Borlak J (2010) NKX2-5: an update on this hypermutable homeodomain protein and its role in human congenital heart disease (CHD). Hum Mutat 31(11):1185-1194

97. Reamon-Buettner SM, Sattlegger E, Ciribilli Y, Inga A, Wessel A, Borlak J (2013) Transcriptional defect of an inherited NKX2-5 haplotype comprising a SNP, a nonsynonymous and a synonymous mutation, associated with human congenital heart disease. PLoS One 8(12):e83295

98. Qiao XH, Wang F, Zhang XL, Huang RT, Xue S, Wang J et al (2017) MEF2C loss-of-function mutation contributes to congenital heart defects. Int J Med Sci 14(11):1143-1153 
99. Lu CX, Wang W, Wang Q, Liu XY, Yang YQ (2018) A novel MEF2C loss-offunction mutation associated with congenital double outlet right ventricle. Pediatr Cardiol 39(4):794-804

100. Pikkarainen S, Tokola H, Kerkela R, Ruskoaho H (2004) GATA transcription factors in the developing and adult heart. Cardiovasc Res 63(2):196-207

101. Misra C, Sachan N, McNally CR, Koenig SN, Nichols HA, Guggilam A et al (2012) Congenital heart disease-causing Gata4 mutation displays functional deficits in vivo. PLoS Genet 8(5):e1002690

102. Chen MW, Pang YS, Guo Y, Liu BL, Shen J, Song HD et al (2009) Association between GATA-4 mutations and congenital cardiac septal defects in Han Chinese patients. Zhonghua Xin Xue Guan Bing Za Zhi 37(5):409-412

103. Chen J, Qi B, Zhao J, Liu W, Duan R, Zhang M (2016) A novel mutation of GATA4 (K300T) associated with familial atrial septal defect. Gene. 575(2 Pt 2): 473-477

104. Butler TL, Esposito G, Blue GM, Cole AD, Costa MW, Waddell LB et al (2010) GATA4 mutations in 357 unrelated patients with congenital heart malformation. Genet Test Mol Biomarkers 14(6):797-802

105. Steimle JD, Moskowitz IP (2017) TBX5: a key regulator of heart development. Curr Top Dev Biol 122:195-221

106. Ryan K, Chin AJ (2003) T-box genes and cardiac development. Birth Defects Res C Embryo Today 69(1):25-37

107. Dressen M, Lahm H, Lahm A, Wolf K, Doppler S, Deutsch MA et al (2016) A novel de novo TBX5 mutation in a patient with Holt-Oram syndrome leading to a dramatically reduced biological function. Mol Genet Genomic Med 4(5):557-567

108. Postma AV, van de Meerakker JB, Mathijssen IB, Barnett $P$, Christoffels VM, Ilgun A et al (2008) A gain-of-function TBX5 mutation is associated with atypical Holt-Oram syndrome and paroxysmal atrial fibrillation. Circ Res 102(11):1433-1442

109. Baban A, Postma AV, Marini M, Trocchio G, Santilli A, Pelegrini M et al (2014) Identification of TBX5 mutations in a series of 94 patients with tetralogy of Fallot. Ame J Med Genet A 164a(12):3100-3107

110. Liu CX, Shen AD, Li XF, Jiao WW, Bai S, Yuan F et al (2009) Association of TBX5 gene polymorphism with ventricular septal defect in the Chinese Han population. Chin Med J 122(1):30-34

111. Xin N, Qiu GR, Gong LG, Xu XY, Sun KL (2009) The mechanism of TBX5 abnormal expression in simple congenital heart disease. Yi Chuan 31(4):374-380

112. Qiao XH, Wang Q, Wang J, Liu XY, Xu YJ, Huang RT et al (2018) A novel NR2F2 loss-of-function mutation predisposes to congenital heart defect. Eur J Med Genet. 61(4):197-203

113. Yang $Y$, Xia $Y$, Wu Y, Huang S, Teng $Y$, Liu X et al (2019) Ankyrin repeat domain 1: a novel gene for cardiac septal defects. J Gene Med 21(4):e3070

114. Huang RT, Xue S, Wang J, Gu JY, Xu JH, Li YJ et al (2016) CASZ1 loss-offunction mutation associated with congenital heart disease. Gene. 595(1): 62-68

115. Sun YM, Wang J, Qiu XB, Yuan F, Li RG, Xu YJ et al (2016) A HAND2 loss-offunction mutation causes familial ventricular septal defect and pulmonary stenosis. G3 6(4):987-992

116. Li L, Wang J, Liu XY, Liu H, Shi HY, Yang XX et al (2017) HAND1 loss-offunction mutation contributes to congenital double outlet right ventricle. Int J Mol Med 39(3):711-718

117. Postma AV, van Engelen K, van de Meerakker J, Rahman T, Probst S, Baars MJ et al (2011) Mutations in the sarcomere gene MYH7 in Ebstein anomaly. Circ Cardiovasc Genet 4(1):43-50

118. Kumar A, Crawford K, Close L, Madison M, Lorenz J, Doetschman T et al (1997) Rescue of cardiac alpha-actin-deficient mice by enteric smooth muscle gamma-actin. Proc National Acad Sci USA. 94(9):4406-4411

119. Klaassen S, Probst S, Oechslin E, Gerull B, Krings G, Schuler P et al (2008) Mutations in sarcomere protein genes in left ventricular noncompaction. Circulation. 117(22):2893-2901

120. Ameres SL, Zamore PD (2013) Diversifying microRNA sequence and function. Nat Rev Mol Cell Biol 14(8):475-488

121. Fischer SE (2015) RNA interference and microRNA-mediated silencing. Curr Protoc Mol Biol 112:26.1.1-26.1.5

122. Mohr AM, Mott JL (2015) Overview of microRNA biology. Semin Liver Dis 35(1):3-11

123. Smith T, Rajakaruna C, Caputo M, Emanueli C (2015) MicroRNAs in congenital heart disease. Ann Transl Med 3(21):333

124. Treiber T, Treiber N, Meister G (2019) Regulation of microRNA biogenesis and its crosstalk with other cellular pathways. Nat Rev Mol Cell Biol 20(1):5-20
125. Eiring AM, Harb JG, Neviani P, Garton C, Oaks JJ, Spizzo R et al (2010) miR328 functions as an RNA decoy to modulate hnRNP E2 regulation of mRNA translation in leukemic blasts. Cell. 140(5):652-665

126. Vasudevan S, Tong Y, Steitz JA (2007) Switching from repression to activation: microRNAs can up-regulate translation. Science. 318(5858):1931-1934

127. Das S, Ferlito M, Kent OA, Fox-Talbot K, Wang R, Liu D et al (2012) Nuclear miRNA regulates the mitochondrial genome in the heart. Circulation Res 110(12):1596-1603

128. Lehmann SM, Kruger C, Park B, Derkow K, Rosenberger K, Baumgart J et al (2012) An unconventional role for miRNA: let-7 activates toll-like receptor 7 and causes neurodegeneration. Nat Neurosci 15(6):827-835

129. Yan HL, Hua YM. Research advances on role of microRNAs in congenital heart diseases. Zhongguo dang dai er ke za zhi $=$ Chinese $J$ Contemp Pediatr 2014;16(10):1070-1074

130. Hoelscher SC, Doppler SA, Dressen M, Lahm H, Lange R, Krane M (2017) MicroRNAs: pleiotropic players in congenital heart disease and regeneration. J Thorac Dis 9(Suppl 1):S64-s81

131. Xie WQ, Zhou L, Chen Y, Ni B (2016) Circulating microRNAs as potential biomarkers for diagnosis of congenital heart defects. World J Emerg Med 7(2):85-89

132. Tian J, An X, Niu L (2017) Role of microRNAs in cardiac development and disease. Exp Ther Med 13(1):3-8

133. Cao L, Kong LP, Yu ZB, Han SP, Bai YF, Zhu J et al (2012) microRNA expression profiling of the developing mouse heart. Int J Mol Med 30(5): 1095-1104

134. Li D, Ji L, Liu L, Liu Y, Hou H, Yu K et al (2014) Characterization of circulating microRNA expression in patients with a ventricular septal defect. PLoS One 9(8):e106318

135. Sucharov CC, Sucharov J, Karimpour-Fard A, Nunley K, Stauffer BL, Miyamoto SD (2015) Micro-RNA expression in hypoplastic left heart syndrome. J Cardiac Fail 21(1):83-88

136. Pulignani S, Vecoli C, Sabina S, Foffa I, Ait-Ali L, Andreassi MG (2016) 3'UTR SNPs and haplotypes in the GATA4 gene contribute to the genetic risk of congenital heart disease. Rev Esp Cardiol (Engl Ed) 69(8):760-765

137. Wang L, Tian D, Hu J, Xing H, Sun M, Wang J et al (2016) MiRNA-145 regulates the development of congenital heart disease through targeting FXN. Pediatr Cardiol 37(4):629-636

138. Zhou Y, Jia WK, Jian Z, Zhao L, Liu CC, Wang Y et al (2017) Downregulation of microRNA199a5p protects cardiomyocytes in cyanotic congenital heart disease by attenuating endoplasmic reticulum stress. Mol Med Rep 16(3): 2992-3000

139. Huang J, Li X, Li H, Su Z, Wang J, Zhang H (2015) Down-regulation of microRNA-184 contributes to the development of cyanotic congenital heart diseases. Int J Clin Exp Pathol 8(11):14221-14227

140. Liu L, Yuan Y, He X, Xia X, Mo X (2017) MicroRNA-1 upregulation promotes myocardiocyte proliferation and suppresses apoptosis during heart development. Mol Med Rep 15(5):2837-2842

141. Guo R, Feng Z, Yang Y, Xu H, Zhang J, Guo K et al (2018) Association of a MiR-499 SNP and risk of congenital heart disease in a Chinese population. Cell Mol Biol 64(10):108-112

142. Mercer TR, Dinger ME, Mattick JS (2009) Long non-coding RNAs: insights into functions. Nat Rev Genet 10(3):155-159

143. Wei JW, Huang K, Yang C, Kang CS (2017) Non-coding RNAs as regulators in epigenetics (review). Oncol Rep 37(1):3-9

144. Gu M, Zheng A, Tu W, Zhao J, Li L, Li M et al (2016) Circulating LncRNAs as novel, non-invasive biomarkers for prenatal detection of fetal congenital heart defects. Cell Physiol Biochem 38(4):1459-1471

145. Garcia-Padilla C, Dominguez JN, Aranega AE, Franco D (2019) Differential chamber-specific expression and regulation of long non-coding RNAs during cardiac development. Biochim Biophys Acta Gene Regul mech 1862(10):194435

146. Duenas A, Exposito A, Aranega A, Franco D (2019) The role of non-coding RNA in congenital heart diseases. J Cardiovasc Dev Dis 6(2):E15.

147. Scheuermann JC, Boyer LA (2013) Getting to the heart of the matter: long noncoding RNAs in cardiac development and disease. EMBO J 32(13):1805-1816

148. Song G, Shen Y, Zhu J, Liu H, Liu M, Shen YQ et al (2013) Integrated analysis of dysregulated IncRNA expression in fetal cardiac tissues with ventricular septal defect. PLoS One 8(10):e77492

149. Cheng Z, Zhang Q, Yin A, Feng M, Li H, Liu H et al (2018) The long noncoding RNA uc.4 influences cell differentiation through the TGF-beta signaling pathway. Exp Mol Med 50(2):e447 
150. Anderson KM, Anderson DM, McAnally JR, Shelton JM, Bassel-Duby R, Olson EN (2016) Transcription of the non-coding RNA upperhand controls Hand2 expression and heart development. Nature. 539(7629):433-436

151. Benhaourech S, Drighil A, Hammiri AE (2016) Congenital heart disease and Down syndrome: various aspects of a confirmed association. Cardiovasc J Afr 27(5):287-290

152. Bergstrom S, Carr H, Petersson G, Stephansson O, Bonamy AK, Dahlstrom A, et al (2016) Trends in congenital heart defects in infants with down syndrome. Pediatrics 138(1):e20160123

153. Antonarakis SE, Lyle R, Dermitzakis ET, Reymond A, Deutsch S (2004) Chromosome 21 and Down syndrome: from genomics to pathophysiology. Nature Rev Genet 5(10):725-738

154. Bondy CA (2009) Turner syndrome 2008. Hormone Res 71(Suppl 1):52-56

155. Pont SJ, Robbins JM, Bird TM, Gibson JB, Cleves MA, Tilford JM et al (2006) Congenital malformations among liveborn infants with trisomies 18 and 13 . Am J Med Genet A 140(16):1749-1756

156. Monteiro RAC, de Freitas ML, Vianna GS, de Oliveira VT, Pietra RX, Ferreira LCA et al (2017) Major contribution of genomic copy number variation in syndromic congenital heart disease: the use of MLPA as the first genetic test. Mol Syndromol 8(5):227-235

157. Costain G, Silversides CK, Bassett AS (2016) The importance of copy number variation in congenital heart disease. NPJ Genom Med 1:16031

158. Wu XL, Li R, Fu F, Pan M, Han J, Yang X et al (2017) Chromosome microarray analysis in the investigation of children with congenital heart disease. BMC Pediatr 17(1):117

159. Oneda B, Rauch A (2017) Microarrays in prenatal diagnosis. Best Pract Res Clin Obstetr Gynaecol 42:53-63

160. Trevisan P, Rosa RF, Koshiyama DB, Zen TD, Paskulin GA, Zen PR (2014) Congenital heart disease and chromossomopathies detected by the karyotype. Rev Paul Pediatr 32(2):262-271

161. Zhu X, Li J, Ru T, Wang Y, Xu Y, Yang Y et al (2016) Identification of copy number variations associated with congenital heart disease by chromosomal microarray analysis and next-generation sequencing. Prenat Diagn 36(4):321-327

162. Shanshen E, Rosenberg J, Van Bergen AH (2018) Identification of novel congenital heart disease candidate genes using chromosome microarray. Pediatr Cardiol 39(1):148-159

163. Mutlu ET, Aykan HH, Karagoz T (2018) Analysis of gene copy number variations in patients with congenital heart disease using multiplex ligationdependent probe amplification. Anatol J Cardiol 20(1):9-15

164. Zhang X, Xu Y, Liu D, Geng J, Chen S, Jiang Z et al (2015) A modified multiplex ligation-dependent probe amplification method for the detection of 22q11.2 copy number variations in patients with congenital heart disease. BMC Genomics 16:364

165. Al-Hassnan ZN, Albawardi W, Almutairi F, AlMass R, AlBakheet A, Mustafa OM et al (2018) Identification of novel genomic imbalances in Saudi patients with congenital heart disease. Mol Cytogenet 11:9

166. Glessner JT, Bick AG, Ito K, Homsy J, Rodriguez-Murillo L, Fromer M et al (2014) Increased frequency of de novo copy number variants in congenital heart disease by integrative analysis of single nucleotide polymorphism array and exome sequence data. Circ Res 115(10):884-896

167. Zhao W, Niu G, Shen B, Zheng Y, Gong F, Wang X et al (2013) Highresolution analysis of copy number variants in adults with simple-tomoderate congenital heart disease. Am J Med Genet A 161a(12):3087-3094

168. Zhu X, Zhang Y, Wang J, Yang JF, Yang YF, Tan ZP (2013) 576 kb deletion in 1p36.33-p36.32 containing SKI is associated with limb malformation, congenital heart disease and epilepsy. Gene. 528(2):352-355

169. Deng Q, Fu F, Li R, Jing X, Lei T, Yang X et al (2017) Application of chromosomal microarray analysis for fetuses with ventricular septal defects. Zhonghua Yi Xue Yi Chuan Xue Za Zhi 34(5):699-704

170. Geng J, Picker J, Zheng Z, Zhang X, Wang J, Hisama F et al (2014) Chromosome microarray testing for patients with congenital heart defects reveals novel disease causing loci and high diagnostic yield. BMC Genomics 15:1127

171. Yan Y, Wu Q, Zhang L, Wang X, Dan S, Deng D et al (2014) Detection of submicroscopic chromosomal aberrations by array-based comparative genomic hybridization in fetuses with congenital heart disease. Ultrasound Obstet Gynecol 43(4):404-412

172. Liu C, Cao R, Xu Y, Li T, Li F, Chen S et al (2018) Rare copy number variants analysis identifies novel candidate genes in heterotaxy syndrome patients with congenital heart defects. Genome Med 10(1):40
173. Goldmuntz E, Paluru P, Glessner J, Hakonarson H, Biegel JA, White PS et al (2011) Microdeletions and microduplications in patients with congenital heart disease and multiple congenital anomalies. Congenit Heart Dis 6(6):592-602

174. Tomita-Mitchell A, Mahnke DK, Struble CA, Tuffnell ME, Stamm KD, Hidestrand $\mathrm{M}$ et al (2012) Human gene copy number spectra analysis in congenital heart malformations. Physiol Genomics 44(9):518-541

175. Sailani MR, Makrythanasis P, Valsesia A, Santoni FA, Deutsch S, Popadin K et al (2013) The complex SNP and CNV genetic architecture of the increased risk of congenital heart defects in Down syndrome. Genome Res 23(9):1410-1421

176. Delea M, Espeche LD, Bruque CD, Bidondo MP, Massara LS, Oliveri J, et al (2018) Genetic imbalances in Argentinean patients with congenital conotruncal heart defects. Genes (Basel) 9(9):E454

177. Amarillo IE, O'Connor S, Lee CK, Willing M, Wambach JA (2015) De novo 9q gain in an infant with tetralogy of Fallot with absent pulmonary valve: patient report and review of congenital heart disease in $9 q$ duplication syndrome. Am J Med Genet A 167a(12):2966-2974

178. Mei M, Yang L, Zhan G, Wang H, Ma D, Zhou W et al (2014) Analysis of genomic copy number variations in two unrelated neonates with $8 p$ deletion and duplication associated with congenital heart disease. Zhonghua Er Ke Za Zhi 52(6):460-463

179. Warburton D, Ronemus M, Kline J, Jobanputra V, Williams I, Anyane-Yeboa K et al (2014) The contribution of de novo and rare inherited copy number changes to congenital heart disease in an unselected sample of children with conotruncal defects or hypoplastic left heart disease. Hum Genet 133(1):11-27

180. Garside VC, Chang AC, Karsan A, Hoodless PA (2013) Co-ordinating Notch, BMP, and TGF-beta signaling during heart valve development. Cell Mol Life Sci 70(16):2899-2917

181. Zhou XL, Liu JC (2014) Role of Notch signaling in the mammalian heart Braz J Med Biol Res 47(1):1-10

182. Nemir M, Pedrazzini T (2008) Functional role of Notch signaling in the developing and postnatal heart. J Mol Cell Cardiol 45(4):495-504

183. MacGrogan D, Nus M, de la Pompa JL (2010) Notch signaling in cardiac development and disease. Curr Top Dev Biol 92:333-365

184. Luxan G, D'Amato G, MacGrogan D, de la Pompa JL (2016) Endocardial notch signaling in cardiac development and disease. Circ Res 118(1):e1-e18

185. Penton AL, Leonard LD, Spinner NB (2012) Notch signaling in human development and disease. Semin Cell Dev Biol 23(4):450-457

186. D'Amato G, Luxan G, de la Pompa JL (2016) Notch signalling in ventricular chamber development and cardiomyopathy. FEBS J 283(23):4223-4237

187. lascone M, Ciccone R, Galletti L, Marchetti D, Seddio F, Lincesso AR et al (2012) Identification of de novo mutations and rare variants in hypoplastic left heart syndrome. Clin Genet 81(6):542-554

188. Yang C, Xu Y, Yu M, Lee D, Alharti S, Hellen N et al (2017) Induced pluripotent stem cell modelling of HLHS underlines the contribution of dysfunctional NOTCH signalling to impaired cardiogenesis. Hum Mol Genet 26(16):3031-3045

189. Kobayashi J, Yoshida M, Tarui S, Hirata M, Nagai Y, Kasahara S et al (2014) Directed differentiation of patient-specific induced pluripotent stem cells identifies the transcriptional repression and epigenetic modification of NKX2-5, HAND1, and NOTCH1 in hypoplastic left heart syndrome. PLoS One 9(7):e102796

190. Kodo K, Ong SG, Jahanbani F, Termglinchan V, Hirono K, InanlooRahatloo K, et al (2016) iPSC-derived cardiomyocytes reveal abnormal TGF-beta ignalling in left ventricular non-compaction cardiomyopathy. Nat Cell Biol 18(10):1031-42.

191. Lim JA, Baek HJ, Jang MS, Choi EK, Lee YM, Lee SJ et al (2014) Loss of beta2-spectrin prevents cardiomyocyte differentiation and heart development. Cardiovasc Res 101(1):39-47

192. Hill MA (2007) Early human development. Clinical Obstetr Gynecol 50(1):2-9

193. Shiota K (2009) Variability in human embryonic development and its implications for the susceptibility to environmental teratogenesis. Birth Defects Res A Clin Mol Teratol 85(8):661-666

194. Schulkey CE, Regmi SD, Magnan RA, Danzo MT, Luther H, Hutchinson AK et al (2015) The maternal-age-associated risk of congenital heart disease is modifiable. Nature. 520(7546):230-233

195. Best KE, Rankin J. Is advanced maternal age a risk factor for congenital heart disease? Birth defects research Part A, Clin Mol Teratol 2016;106(6):461-467

196. Chen X, Hu J, Wang J, Ma H, Bai W, Liu Z et al (2015) Clinical epidemiological study of peri-conceptional multiple risk factors and congenital heart diseases. Zhonghua Yi Xue Za Zhi 95(9):701-704 
197. Solorzano-Santos F, Barcenas-Lopez SJ, Huerta-Garcia GC, Miranda-Novales MG, Alvarez YMMT, Vazquez-Rosales JG (2013) Perinatal infection by rubella virus in breast-fed babies with congenital heart disease. Rev Med Inst Mex Seguro Soc 51(2):158-163

198. Yazigi A, De Pecoulas AE, Vauloup-Fellous C, Grangeot-Keros L, Ayoubi JM, Picone $\mathrm{O}$ (2017) Fetal and neonatal abnormalities due to congenital rubella syndrome: a review of literature. J Mat Fetal Neonatal Med 30(3):274-278

199. Fung A, Manlhiot C, Naik S, Rosenberg H, Smythe J, Lougheed J et al (2013) Impact of prenatal risk factors on congenital heart disease in the current era. J Am Heart Assoc 2(3):e000064

200. Karatza AA, Giannakopoulos I, Dassios TG, Belavgenis G, Mantagos SP, Varvarigou AA (2011) Periconceptional tobacco smoking and isolated congenital heart defects in the neonatal period. Int J Cardiol 148(3):295-299

201. Malik S, Cleves MA, Honein MA, Romitti PA, Botto LD, Yang S et al (2008) Maternal smoking and congenital heart defects. Pediatrics. 121(4):e810-e816

202. Watkins ML, Rasmussen SA, Honein MA, Botto LD, Moore CA (2003) Maternal obesity and risk for birth defects. Pediatrics. 111(5 Pt 2):1152-1158

203. Madsen NL, Schwartz SM, Lewin MB, Mueller BA (2013) Prepregnancy body mass index and congenital heart defects among offspring: a populationbased study. Congenit Heart Dis 8(2):131-141

204. Gillboa SM, Correa A, Botto LD, Rasmussen SA, Waller DK, Hobbs CA et al (2010) Association between prepregnancy body mass index and congenital heart defects. Am J Obstetr Gynecol 202(1):51.e1-51e10

205. Basu M, Garg V (2018) Maternal hyperglycemia and fetal cardiac development: clinical impact and underlying mechanisms. Birth Defects Res 110(20):1504-1516

206. Oyen N, Olsen SF, Basit S, Leirgul E, Strom M, Carstensen L et al (2019) Association between maternal folic acid supplementation and congenital heart defects in offspring in birth cohorts from Denmark and Norway. J Am Heart Assoc 8(6):e011615

207. Leirgul E, Gildestad T, Nilsen RM, Fomina T, Brodwall K, Greve G et al (2015) Periconceptional folic acid supplementation and infant risk of congenital heart defects in Norway 1999-2009. Paediatr Perinat Epidemiol 29(5):391-400

208. Ionescu-Ittu R, Marelli AJ, Mackie AS, Pilote L (2009) Prevalence of severe congenital heart disease after folic acid fortification of grain products: time trend analysis in Quebec, Canada. BMJ 338:b1673

209. Roodpeyma S, Kamali Z, Afshar F, Naraghi S (2002) Risk factors in congenital heart disease. Clin Pediatr 41(9):653-658

\section{Publisher's Note}

Springer Nature remains neutral with regard to jurisdictional claims in published maps and institutional affiliations.

\section{Submit your manuscript to a SpringerOpen ${ }^{\circ}$ journal and benefit from:}

- Convenient online submission

- Rigorous peer review

- Open access: articles freely available online

- High visibility within the field

- Retaining the copyright to your article

Submit your next manuscript at $\boldsymbol{\nabla}$ springeropen.com 